\title{
Substitutes for seeds of Vitellaria paradoxa, Parkia biglobosa and Adansonia digitata used for nutrition by five major ethnic groups in Benin, West Africa
}

\author{
Received: 2016-11-22; revised: 2016-11-29; accepted: 2016-12-03
}

\author{
Katja Heubach ${ }^{1,2 *}$, Katharina Schumann ${ }^{3}$, Karen Hahn ${ }^{2,3}$ \\ ${ }^{1}$ Deutsche Gesellschaft für Internationale Zusammenarbeit (GIZ) GmbH, Postfach 5180, D-65726 Eschborn, Germany \\ ${ }^{2}$ Biodiversity and Climate Research Centre (LOEWE BiK-F), Georg-Voigt-Straße 16-18, D-60325 Frankfurt/Main, Germa- \\ ny \\ ${ }^{3}$ Institute of Ecology, Evolution and Diversity, Goethe-University, Max-von-Laue-Straße 13, D-60438 Frankfurt/Main, Ger- \\ many \\ * corresponding author. E-mail address: katja.heubach@giz.de; Tel.: + 496196 79-7288
}

\begin{abstract}
Summary: Non-Timber Forest Products (NTFPs) make a major contribution to the livelihoods and diets of rural households in the savanna ecosystems of West Africa. However, land use change and climatic variability might affect their availability in the future. Based on a survey among 227 households in Northern Benin, we investigated local substitution patterns for the seeds of the three socio-economically most important NTFP-species in the region, Vitellaria paradoxa, Adansonia digitata and Parkia biglobosa, being major sources for protein, fat, and micronutrients in local daily diets. Our study compared substitution patterns between, firstly, three income groups, to assess whether a households' socio-economic status has an influence on the choice of surrogates (low cost vs. more costly options). Secondly, we compared substitution patterns between the five major ethnic groups in the study region (the Fulani, the Bariba, the Ditammarie, the Kabiyé and the Yom). The choice of substitutes differed significantly across income groups. However, the poorest households clearly show to be the most vulnerable: up to $30 \%$ of the sampled households stated they would lack an adequate replacement for the NTFPs in question. Furthermore, ethnic affiliation showed to have a considerable impact on the preferred alternative products due to underlying cultural traditions of plant use. Subsequently, aiming at maintaining - and enhancing - the local supply of $V$. paradoxa, $P$. biglobosa and $A$. digitata in order to secure their contributions to local diets, local land use policy should have a particular focus on their ethnic-conditioned use and particularly the specific requirements of the poorest community members.
\end{abstract}

Key words: Livelihood, non-timber forest products, NTFPs, rural income, forest dependency, West Africa, savanna ecosystem, rural poor

\section{Substitut des gRaines de Vitellaria PARAdOXA, PARKIA BIGlobOSA et ADANSONIA DIGITATA UTILI- SÉES POUR LA NUTRITION PAR CINQ GROUPES ETHNIQUES MAJEURS AU BÉNIN, AFRIQUE DE L'OUEST}

Résumé: Les produits forestiers non ligneux (PFNL) apportent une contribution majeure aux besoins quotidiens et aux régimes alimentaires des ménages ruraux dans les écosystèmes des savanes d'Afrique de l'Ouest. Cependant, le changement de l'occupation du sol et la variabilité climatique pourraient affecter leur disponibilité dans l'avenir. Sur la base d'une enquête menée auprès de 227 ménages du nord du Bénin, nous avons étudié les modèles de substitution locale pour les produits alimentaires des trois espèces de PFNL socio-économiquement les plus importantes de la région, Vitellaria paradoxa, Adansonia digitata et Parkia biglobosa. Leurs graines sont une importante source de protéines, lipides et micronutriments. Notre étude a comparé les schémas de substitution entre, premièrement, trois groupes de revenu afin d'évaluer si le statut socioéconomique des ménages aurait une influence sur le choix des substituts (coût faible par rapport aux options plus coûteuses). Deuxièmement, nous avons comparé les modes de substitution entre les cinq principaux groupes ethniques dans la région étudiée (Fulani, Bariba, Ditammarie, Kabiyé et Yom). Le choix des substituts différait considérablement d'un groupe de revenu à l'autre. Cependant, les ménages les plus pauvres sont clairement les plus vulnérables: jusqu'à 30\% des ménages échantillonnés ont déclaré qu'ils n'auraient pas un remplaçant approprié pour les PFNL en question. De plus, l'appartenance ethnique s'est révélée avoir un impact considérable sur les produits alternatifs préférés en raison des traditions culturelles sous-jacentes de l'utilisation des plantes. Par la suite, dans le but de maintenir - et d'améliorer - l'approvisionnement local de $V$. paradoxa, $P$. biglobosa et $A$. digitata afin d'assurer leur contribution aux régimes alimentaires des ménages ruraux, la politique locale d'utilisation des terres devrait porter une attention particulière à leur utilisation, surtout aux besoins spécifiques des membres les plus pauvres de la communauté.

Mots clés: Ressources de base, produits forestiers non ligneux, PFNL, revenu rural, dépendance des forêts, Afrique de l'Ouest, savane, populations rurales pauvres

\section{UNTERSUCHUNG ZUR SUBSTITUIERUNG DER IN DER ERNÄHRUNG GENUTZTEN SAMEN VON VITELLARIA PA- RADOXA, PARKIA BIGLOBOSA UND AdANSONIA DIGITATA BEI FÜNF ETHNISCHEN GRUPPEN IN BENIN, WEST- AFRIKA}

Zusammenfassung: Essbare Wildpflanzen stellen wichtige Nahrungsergänzungen, zu einer ansonsten nährstoffarmen Ernährung ländlicher Nichtholz-Forstprodukte (non-timber forest products, NTFPs) leisten einen wesentlichen Beitrag zu den Lebensgrundlagen und der Ernährung ländlicher Haushalte in den Savannenökosystemen Westafrikas. Landnutzungsänderungen und klimatische Variabilität könnten ihre Verfügbarkeit in Zukunft jedoch beeinträchtigen. Basierend auf einer Befra- 
gung von 227 Haushalten in Nord-Benin untersuchten wir die lokalen Substitutionsmuster für die in der Ernährung genutzten Samen der drei sozioökonomisch wichtigsten NTFP-Arten in der Region, Vitellaria paradoxa, Adansonia digitata und Parkia biglobosa, die wesentliche Quellen für essentielle Proteine, Fett und Mikronährstoffe sind. Unsere Studie verglich zunächst die Substitutionsmuster zwischen drei Einkommensgruppen, um festzustellen, ob der sozioökonomische Status der privaten Haushalte einen Einfluss auf die Wahl der Substitute haben würde (geringere versus höhere Kosten bei der Beschaffung dieser Substitute). Zweitens verglichen wir die Substitutionsmuster zwischen den fünf großen ethnischen Gruppen des Untersuchungsgebietes (Fulani, Bariba, Ditammarie, Kabiyé und Yom). Die Wahl der Substitute unterschied sich signifikant zwischen den drei Einkommensgruppen, wobei die ärmsten Haushalte die höchste Vulnerabilität aufweisen: Bis zu 30\% der in die Stichprobe einbezogenen Haushalte gaben an, dass ihnen ein angemessener Ersatz für die betreffenden NTFP fehle. Darüber hinaus zeigte die ethnische Zugehörigkeit einen erheblichen Einfluss auf die bevorzugten Alternativprodukte, der auf die unterschiedlichen kulturellen Traditionen bei der Nutzung der NTFPs zurückzuführen ist. Mit Blick auf die Sicherung der Beiträge von $V$. paradoxa, P. biglobosa und A. digitata zur lokalen Ernährung bzw. deren Verbesserung, sollte lokale Landnutzungspolitik die ethnisch bedingten Unterschiede in der Nutzung der NTFPs sowie die besonderen Bedürfnisse der unteren Einkommensgruppen stärker berücksichtigen.

Schlagworte: Nicht-Holz-Waldprodukte, NTFPs, ländliche Einkommen, Wald als Lebensgrundlage, Westafrika, Savanne, ländliche Entwicklung

\section{INTRODUCTION}

Non-timber Forest Products (NTFPs), i.e. products from wild plant and animal species, are inherent to the social-cultural traditions and livelihoods of rural African communities (CAVEndish 2000; LyKKe et al. 2004; Shackleton et al. 2008; KALABA et al.; 2013a). NTFPs comprise all biological matters except sawn timber but including small wooden poles and stick to be harvested without technological requirements from forests and woodlands (CIFOR, 2011). Fruits, leaves, barks and other vegetable structures, as well as animal products, make important contributions to people's daily diets (Angelsen et al., 2014; Heubach et al. 2011), are used as firewood (Belcher 2003; Cunningham et al. 2002), medicine (e.g., NdAM \& MARCELIN 2004; BundSCHUH et al. 2011) and construction material (HeUBACH et al. 2013), and play essential roles in indigenous belief systems (CAVENDish 2002; ANGelsen \& Wunder 2003; FopPES \& KETPHANH 2004; CIFOR 2015). NTFPs are crucial to the socio-economic viability of households in rural areas worldwide. In unfavorable situations, e.g. famine or financial shocks, they provide a safety-net by filling gaps in consumption or cash income (BABULO et al. 2009; KAMANGA et al. 2009; World Agroforestry Center 2013). Globally, 1.6 billon people are considered being highly forest dependent (World Bank 2004, 2008).

In rural sub-Saharan Africa, more than half of the population relies on food harvested from their direct environment (World Resources Institute 2005), next to locally grown crops). A growing body of case studies gives evidence for the particular contribution of NTFPs to the economies of households living in rural agroforestry systems, both in terms of subsistence and cash income. For example, in Malawi, total income shares from fruit tree products only accounted for $15 \%$ of household income (KAMANGA et al. 2009), and in the Republic of Congo wild plant products contributed up to $10 \%$ to local income (DE Merode et al. 2004). Assessing a larger set of forest products (incl. wooden and selected animal products), a study in Ethiopia found NTFPs to make up $27 \%$ (BABULO et al. 2009), and one in Zimbabwe (including non-renewable NTFPs) even $35 \%$ of rural household income (CAVENDISH 2000). Furthermore, a recent study in Northern Benin revealed wild plants to constitute on average $39 \%$ of household cash and subsistence income (Heubach et al. 2011). In most of the studies NTFPs are characterized by open or semi-open access and their collection does not require special technical equipment or financial means, thus, representing highly beneficial sources for livelihoods particularly for the rural poor (ANGELSEN \& WUNDER 2003; VEDELD et al. 2007).

The variety of used species thereby is enormous. Particularly plant species are fundamental ingredients in daily consumption, important for construction and energy supply, and essential for medical treatment - mostly with multiple uses. For example, in the study area located in the south Sudanian zone of Benin more than 90 woody species are locally used, often for multiple uses, such as traditional medicine (61\% of the 90 woody species are used for that), dental care (49\% of the 90 species), firewood (41\% of the 90 species), construction (39\% of the 90 species), and wild foods (32\% of the 90 species) (Heubach et al. 2013). Likewise, amongst others, VodouHÉ (2009) identified more than 70 plant species used daily by people living adjacent to the Pendjari National Park in Northern Benin, and LyKKE et al. (2004) identified 56 woody multi-use species highly valued by rural communities in the Sahel area of Burkina Faso.

However, use preferences for species might differ much within the studied communities. Based on their traditional knowledge and cultural backgrounds, specific social groups show differences in the collection and use of a specific set of plants. According to KEPE (2008) social differentiaion is a key factor determining resource use in forest-based communities due to social affiliations to certain groups or networks (e.g., ethnic groups, user groups) and individual characteristics. In this context, recent studies in Benin and Burkina Faso shed light on the role ethnic affiliation plays with regard to plant use. In addition to individual household characteristics, such as e.g. age, gender, location, and access to farmland, ethnicity appeared to be highly influencing use values for woody plant species (CALUwÉ et. al. 2009; FANDOHAN et al. 2010; SCHUMANN 2011; GouWAKINNOU et al. 2011; Heubach et al. 2013).

Recently, there is growing concern that the occurrence of NTFP-providing plant species has been continuously negatively impacted by land use change, e.g. through the ongoing conversion of savanna areas into cultivated land (BRINK \& Eva 2009), introduction of alien species (SHACKLETON et al. 2007), agricultural intensification (WITTIG et al. 2007), amongst others. Moreover, predicted climatic changes are likely to change future occurrences of plant species (IPCC 2007), including in our study region (WITTIG et 
al. 2007). With regard to the three socio-economically most important woody species in Northern Benin - Vitellaria paradoxa, Parkia biglobosa and Adansonia digitata (VoDOUHÊ et al. 2009; FANDOHAN et al. 2010; Heubach et al. 2013) - Heubes et al. (2012) predicted a severe decrease in their occurrence in 2050 due to climate and land use change. Thus, it is of interest to assess whether and which alternatives rural communities might draw on to compensate current and possible future outage of those NTFPs they use largely for their daily consumption.

The study at hand investigated the general, current substitution patterns of households in case of temporary shortages for the three socio-economically most important woody species in the region (and in other areas of the Sudanian zone: see e.g. LeSSMEISTER et al. 2015) Vitellaria paradoxa, Parkia biglobosa, and Adansonia digitata (Vodounê et al. 2009; FAndohan et al. 2010; Heubach et al. 2013). Shortterm NTFP shortage might be caused by inter-annual variations in NTFP availabilities, low rainfall and/or depleted stocks before the next harvest season. We explored current substitution patterns among the five major ethnic groups (the Fulani, the Ditammarie, the Kabiyé, the Bariba, and the Yom) in two villages in Northern Benin.

While $V$. paradoxa seeds are a key source for fat (MARANZ et al. 2004), P. biglobosa and A. digitata seeds provide valuable protein (TekLehaimanot 2004). Protein contents of the fermented $P$. biglobosa seeds even can exceed that of meat (KRONBORG et al. 2014). Besides, all of them add essential vitamins (TeKLehaimanot 2004) to local diets. Being still available in the dry season (fruits of $P$. biglobosa and $A$. digitata), when fields are already harvested, and being suitable for mid-term storage, these species' seeds are excellent to overcome times of seasonal or financial shortcomings (SCHRECKENBERG et al. 2006; ARNOLD et al. 2011).

Potential sources for substitutes for these three species' seeds may be parts of other wild NTFP-providing species found in the adjacent savanna area, or of cultivated or purchased plants, animal products, or other marketed natural or manufactured goods. The choice of the replacement might, firstly, depend on their socio-economic status, i.e. their financial means allowing for more or less costly options. Secondly, as elaborated on above, ethnicity might play a major role in choosing substitutes, since ethnic affiliation comes along with particular knowledge on and traditions of plant and other product use. Thirdly, the choice of the substitute might also account for its potential to adequately complement for the nutritional values of the replaced NTFP.

Our study, thus, identifies households' current choice of substitutes for seeds of $V$. paradoxa, P. biglobosa and A. digitata, comparing i) three income groups, and ii) five ethnic groups. Additionally, we reflect on whether the substitutes meet nutritional values equaling those of the investigated NTFPs (based on existing figures from the literature), and draft options for adaptive measures to possible changes in NTFP supply.

\section{STUdY CONTEXT}

\subsection{Characteristics of the study area}

\subsubsection{Socio-economic setting of studied villages}

We conducted our study in two villages in Northern Benin, Papatia and Chabi-Couma (30 km apart), in the Department of Atakora (Fig. 1) approximately $35 \mathrm{~km}$ from the northern economic urban center Natitingou. In 2008, of the Department population $62.3 \%$ lived in rural areas and $70.3 \%$ were considered poor.

We considered two villages to obtain a replication. Thus, our selection was based on the similarity of the two villages in terms of their socio-economic profile. Both are endowed with piped water, an own small local market, and a primary school. They are located in a similar distance from the urban center and the main road, i.e. have similar access to urban facilities and products. Both have only rudimentary access to electricity, and households' energy demands are primarily met by firewood collected in the adjacent savanna areas. Major ethnic groups located in the area are spread evenly in both villages.

Residents of these villages are mainly engaged in rain-fed crop production in agroforestry systems, small livestock husbandry and NTFP collection in the adjacent savanna areas. Off-farm income (e.g. local trading, tailor, motorbike taxi driver, employment in administrative and educational activities) is very rare. The importance of NTPF collection was conformed and underlined by SIEGLSTETTER et al. (2011), who found that $96 \%$ of the 129 woody species existing in a neighbouring area were used.

\subsubsection{Biophysical environment}

Belonging to the southern Sudanian zone with tropical climate and a rainy season from May to November, the savanna ecosystems in the study region are covered by tree and shrub savanna (MAYAUX \& BARTHOLOMÉ 2003). As a result of the traditional small holder system of slash-and-burn agriculture in shifting cultivation, the agroforestry parklands show a pattern of old and young fields and fallows with selected multi-use trees spared from chopping.

\subsubsection{Ethnic groups}

The five major ethnicities domiciled in the studied villages are the four tiller societies Bariba (autochthon, i.e. the original settlers in the region), Ditammarie, Kabiyé (both migrated from Togo) and Yom (originally from the Department of Bassila, south of the study area), as well as the pastoralist Fulani (from Kouandé, east of the Atakora chain) who settled in the region due to severe drought events (DE BRUIJN \& DiJK 1994; Bolwig \& PAarup-Laursen 1999). All ethnic groups are similar in terms of household size, age and education of head, with insignificant differences with regard to total household income and distribution into income groups (Table 1) (Heubach et al. 2011). Access to the savanna areas is traditionally semi-open. While within the village area particular sectors for harvesting NTFPs are exclusively assigned to the different local ethnic groups, access to 
Table 1: Comparison of socio-economic characteristics of investigated ethnic groups in Papatia and Chabi-Couma ( $\mathrm{N}=227$ households; modified after Heubach et al., 2011). / Comparaison des caractéristiques socio-économiques des groupes ethniques étudiés à Papatia et Chabi-Couma $(\mathrm{N}=227$ ménages, modifiés après HeUBACH et al. 2011).

\begin{tabular}{|c|c|c|c|c|c|}
\hline $\mathbf{N}=\mathbf{2 2 7}$ & Bariba & Ditammarie & Kabiyé & Yom & Fulani \\
\hline Main employment: tiller (\%) & 98 & 96 & 100 & 100 & 93 \\
\hline Main employment: livestock breeder (\%) & - & - & - & - & 5 \\
\hline Total household income (in Euro, per aeu* and year) & 731 & 694 & 644 & 690 & 704 \\
\hline Very low income group $(\%)$ & 28 & 35 & 28 & 39 & 37 \\
\hline Medium income group (\%) & 43 & 29 & 30 & 34 & 33 \\
\hline Above medium income group $(\%)$ & 28 & 35 & 42 & 27 & 30 \\
\hline
\end{tabular}

*aeu $=$ adult equivalent units (DEATON, 1982), i.e. mean income displays the adjusted income per person in the respective household

savanna resources beyond village level is unrestricted. Harvest of trees on farmland remains restricted to the farmland owners. Migrants who have borrowed land don't have rights to the products of the trees on these lands.

\subsection{Investigated NTFP species}

The selection of the NTFP-providing species to study here is based on the findings of Неubach et al. (2013) who found V. paradoxa, P. biglobosa and A. digitata to be the three woody species valued the most by rural communities in the region. They contribute to daily dietary needs in terms of fat, protein, and vitamins contained in their seeds, and present a large share to total household income (Table 2).

\section{Methods}

\subsection{Study design, data collection and data analysis}

The data used in this analysis is part of a household survey on NTFP collection, use and socio-economic characteristics that was conducted with 227 randomly selected households in two villages (Chabi-Couma and Papatia) in Northern Benin, West Africa in 2009. The households were stratified according to their ethnic affiliation to one of the five major ethnic groups in the region, i.e. the Bariba, the Kabiyé, the Fulani, the Ditammarie and the Yom $(45,45,45,46$, and 46 interviews, respectively).

Being the main collectors of NTFPs, women were asked to report substitutes used in diets when seeds of Vitellaria paradoxa, Parkia biglobosa and Adansonia digitata are not available due to temporal and/or seasonal shortage, e.g. when stocks are depleted before the next harvest. We did not

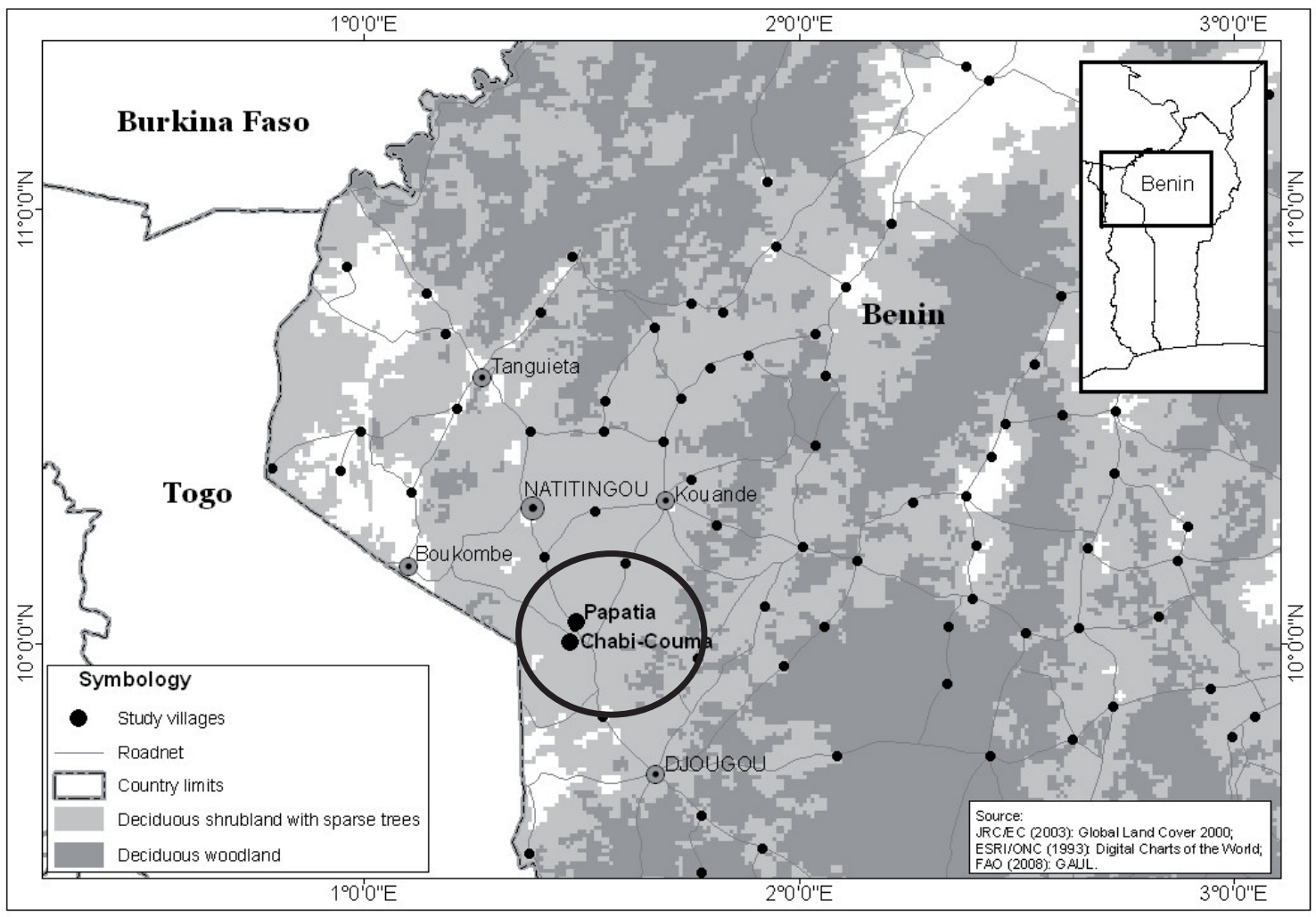

Fig. 1: Map of the study area (Department of Atakora) with the two studied villages Papatia and Chabi-Couma. Large black dots (labelled) represent the two study villages; other smaller black dots (unlabelled) are displayed in order to represent the density of villages located within the savannah ecosystem. / Carte de la zone d'étude (Département d'Atakora) avec les deux villages étudiés Papatia et Chabi-Couma. De grands points noirs (étiquetés) représentent les deux villages étudiés; d'autres points plus petits (non étiquetés) sont affichés pour montrer la densité des villages situés dans l'écosystème de la savane. 
Table 2: Contributions by the three target species Vitellaria paradoxa, Parkia biglobosa and Adansonia digitata to local dietary needs, and related consumption and market patterns. / Contributions des trois espèces cibles Vitellaria paradoxa, Parkia biglobosa et Adansonia digitata aux besoins alimentaires locaux, ainsi que des modèles de consommation et de commerce respectifs.

\begin{tabular}{|c|c|c|}
\hline Species & Product and contribution to local diet & Consumption and market pattern \\
\hline \multirow[t]{2}{*}{$\begin{array}{l}\text { Vitellaria paradoxa } \\
\text { (subspecies paradoxa, Shea Tree, } \\
\text { local French name: Karité) }\end{array}$} & $\begin{array}{l}\text { Shea nuts (kernels): contain up to } 50 \% \text { fatty acids } \\
\text { (TEKLEHAIMANOT 2004); processed into shea butter } \\
\text { ('beurre du Karité') used as cooking oil and for skin } \\
\text { care }\end{array}$ & $\begin{array}{l}\text { Average annual consumption of Shea butter in sub- } \\
\text { Saharan countries ranges between } 7.3 \text { up to } 10 \mathrm{~kg} \\
\text { per person (BOFFA 1999; DAH-DovOvON 2006) }\end{array}$ \\
\hline & $\begin{array}{l}\text { Fruit pulp: excellent source of protein, calcium and } \\
\text { sugar (MARANZ et al. 2004) }\end{array}$ & $\begin{array}{l}\text { In } 2009 \text {, the average share of income from } V \text {. pa- } \\
\text { radoxa in total household income in the study area } \\
\text { was } 13 \% \text {, and } 89 \% \text { of collected shea nuts were } \\
\text { sold on local markets (HeubACH et al. 2013) }\end{array}$ \\
\hline \multirow{3}{*}{$\begin{array}{l}\text { Parkia biglobosa } \\
\text { (African Locust Bean Tree or Néré) }\end{array}$} & \multirow{3}{*}{$\begin{array}{l}\text { Seeds: protein-rich with multiple essential amino } \\
\text { acids (NoRDEIDE et al. 1996); fermented and pro- } \\
\text { cessed as local ingredient in sauces ('moutarde'); } \\
\text { protein content is equal to or even higher than that } \\
\text { of various kinds of meat (KRONBORG et al. 2014) }\end{array}$} & $\begin{array}{l}\text { Highly valued as staple food throughout West Africa } \\
\text { (MERTz et al., 2001) }\end{array}$ \\
\hline & & \multirow{2}{*}{$\begin{array}{l}\text { In } 2009 \text {, the average share of income from } P . \text { bi- } \\
\text { globosa in total household income in the study area } \\
\text { was } 10 \% \text {, and } 88 \% \text { of collected seeds were sold on } \\
\text { local markets (HeuBACH et al. 2013) }\end{array}$} \\
\hline & & \\
\hline $\begin{array}{l}\text { Adansonia digitata } \\
\text { (African Baobab) }\end{array}$ & $\begin{array}{l}\text { Seeds: rich in protein and fat (DE CALUWÉ et al. } \\
\text { 2009); roasted seeds used as ingredient in sauces } \\
\text { and as snack food; also as alternative to coffee; by } \\
\text { pounding or boiling, the seed's oil can be extracted }\end{array}$ & $\begin{array}{l}\text { In } 2009 \text {, the average share of income from } A \text {. digi- } \\
\text { tata in total household income in the study area was } \\
2 \% \text {, and } 73 \% \text { of collected seeds were sold on local } \\
\text { markets (HEUBACH et al. } 2013 \text { ) }\end{array}$ \\
\hline
\end{tabular}

ask about changes in the availability of the three NTFPs or whether their reliance on them had increased.

On basis of the income data collected through the questionnaire, we calculated total household income. In accordance with CAVENDISH (2002), we defined a household's total income as the sum of cash income generated from various activities (e.g. crop and livestock production, collection of wild foods, small-scale activities) and the monetary equivalent of a household's subsistence use of the output of these activities. Total household income is accounted on annual basis. It reflects the net income generated by the population sample under investigation, i.e. the total value of output deducted by the total value of input (e.g. fertilizer for agricultural production, veterinary supplies) during the accounted period. Note that net income includes own-labor costs due to absent or thin labor markets in rural African settlements. To calculate income, we used means of local market prices (observed monthly at the two markets of Papatia and ChabiCouma during the study period) and households' own-reported revenues from selling their products (in local units of measure - 'aguwe'). Both market prices and own-reported revenues were found to be strongly consistent for both agricultural and woodland products. In order to account for the varying compositions (number and sex of adults and children) of the studied households, we applied a combination of the OECD-modified equivalence scale due to type of household member (HAGENAARS et al. 1994) and used an economy-of-scale coefficient resulting in household size as the determinant of needs suggested by DEATON (1982). The adjusted income (all income sources) then equals income per adult equivalent units (aeu).

In order to compare NTFP substitution between income groups, we split the sample into income terciles: "very low income group" $(\mathrm{N}=73)$, "medium income group" $(\mathrm{N}=73)$ and "above medium income group" $(\mathrm{N}=72)$. Mean annual total income per aeu (adult equivalent unit, i.e. adjusted income, according to DEATON (1982)), between income groups was significantly different $(406 €, 669 €$, and $1017 €$, respectively; ANOVA p $<0.001$ ).

The substitutes reported in the interviews were grouped into three categories reflecting their origin: i) product of a culti- vated/purchased plant, ii) product of other wild plant species, and iii) purchased animal or other product. Chi-square test was used to compare the counts of the three categories between income groups, ethnicities and villages. Chi-square tests were performed using IBM SPSS Statistics 22 (IBM 2013).

\section{Results}

\subsection{Substitutes for seeds of Vitellaria paradoxa, Parkia biglobosa and Adansonia digitata}

Table 3 shows the results of the survey on NTFP substitutes. Asked for possibilities to substitute the seeds of $V$. paradoxa, women reported three possibilities, of which two are cultivated/purchased plants. More than half of the respondents declared that shea butter could be replaced by palm oil derived from the palm tree Elaeis guineensis, and one third mentioned to preferably substitute it by peanut oil. Only a negligible proportion of respondents mentioned to replace $V$. paradoxa seeds by butter from cow milk.

For P. biglobosa seeds, in total 12 substitutes were reported. They comprise eight products from cultivated/purchased plants (in decreasing importance: peanuts, chilies, onions, sesame, beans, Blighia sapida, soybeans), three purchased animal/ other products (in decreasing importance: fish, MAGGI cubes - product by Nestlé, salt), and one alternative wild plant species (Ceiba pentandra). The most quoted products were fish, MAGGI cubes (food flavoring product by Nestlé, main ingredient: salt, frequently used), peanut, and chilies.

The seeds of $A$. digitata can be substituted by five cultivated/purchased plants (in decreasing importance: sesame, peanuts, B. sapida, lady's fingers, tomato and two other wild plant species (Vitex doniana, Parinari curatellifolia). However, only three cultivated plants - sesame, peanut, and the seeds of B. sapida - were frequently quoted, while the other products were mentioned by very few respondents.

In general, cultivated/purchased plants were the predominant cited substitute category for all three studied species. 
Table 3: Substitutes for seeds of Vitellaria paradoxa, Parkia biglobosa, and Adansonia digitata. The assignment of each substitute to one of the three categories is also presented. / Substituts aux graines de Vitellaria paradoxa, Parkia biglobosa et Adansonia digitata. Le classement de chaque substitut dans une des trois catégories est également présenté.

\begin{tabular}{|c|c|c|c|c|c|}
\hline Substitute & Plant part & $\%$ of respondents & $\begin{array}{l}\text { Product of a culti- } \\
\text { vated or purchased } \\
\text { plant species }\end{array}$ & $\begin{array}{l}\text { Product of a } \\
\text { wild plant spe- } \\
\text { cies }\end{array}$ & $\begin{array}{l}\text { Purchased ani- } \\
\text { mal or other } \\
\text { products }\end{array}$ \\
\hline \multicolumn{6}{|l|}{ Vitellaria paradoxa } \\
\hline Oil of Elaeis guineensis & fruits & 57.9 & $\mathrm{x}$ & & \\
\hline Oil of Arachis hypogaea (peanut) & fruits & 29.8 & $\mathrm{x}$ & & \\
\hline Butter made from cow milk & & 0.4 & & & $\mathrm{x}$ \\
\hline no substitutes & & 11.8 & & & \\
\hline \multicolumn{6}{|l|}{ Parkia biglobosa } \\
\hline Fish, smoked & & 28.1 & & & $\mathrm{x}$ \\
\hline MAGGI cubes (Nestlé) & & 20.8 & & & $\mathrm{x}$ \\
\hline Arachis hypogaea (peanut) & seeds & 13.9 & $\mathrm{x}$ & & \\
\hline Capsicum spec. (chilies) & fruits & 4.8 & $\mathrm{x}$ & & \\
\hline Ceiba pentandra & seeds & 3.5 & & $\mathrm{x}$ & \\
\hline Allium cepa (onion) & bulb (dried) & 3.0 & $\mathrm{x}$ & & \\
\hline Sesamum indica (sesame) & seeds & 2.6 & $\mathrm{x}$ & & \\
\hline Salt & & 1.7 & & & $\mathrm{x}$ \\
\hline Phaseolus vulgaris (beans) & seeds (dried) & 1.7 & $\mathrm{x}$ & & \\
\hline Blighia sapida & seeds (aril) & 1.3 & $\mathrm{x}$ & & \\
\hline Glycine max (soybeans) & seeds & 0.9 & $\mathrm{x}$ & & \\
\hline Hibiscus sabdariffa & Seeds (fermented) & 0.9 & $\mathrm{x}$ & & \\
\hline no substitutes & & 16.5 & & & \\
\hline \multicolumn{6}{|l|}{ Adansonia digitata } \\
\hline Sesamum indica (sesame) & seeds & 41.0 & $\mathrm{x}$ & & \\
\hline Arachis hypogaea (peanut) & seeds & 15.4 & $\mathrm{x}$ & & \\
\hline Blighia sapida & seeds (aril) & 14.1 & $\mathrm{x}$ & & \\
\hline \multicolumn{6}{|l|}{ Abelmoschus esculentus } \\
\hline (lady's fingers) & seeds & 1.3 & $\mathrm{x}$ & & \\
\hline Vitex doniana & leaves & 0.9 & & $\mathrm{x}$ & \\
\hline Lycopersicon esculentum (tomato) & fruits, powder & 0.4 & $\mathrm{x}$ & & \\
\hline Parinari curatellifolia & seeds & 0.4 & & $\mathrm{x}$ & \\
\hline no substitutes & & 26.4 & & & \\
\hline
\end{tabular}

For P. biglobosa and V. paradoxa seeds, animal and other products were the second most important category of substitutes, while for $A$. digitata seeds of other wild plant species were the second most frequently cited surrogates.

Peanuts were reported as a substitute for the seeds of all three studied species. In addition, the seeds of sesame and $B$. sapida were likewise mentioned as substitutes for the seeds of $A$. digitata and P. biglobosa.

Substitutes for seeds of P. biglobosa (12 substitutes) are nearly twice as many as for $A$. digitata (7 substitutes), and even four times higher than for $V$. paradoxa (3 substitutes). Furthermore, almost $30 \%$ of respondents stated that they have no substitution for the seeds of $A$. digitata, and 10$20 \%$ of respondents lack replacements for the seeds of $P$. biglobosa and $V$. paradoxa. Interestingly, the three studied NTFP species were not mentioned as substitutes for each other.

\subsection{Differences in substitution patterns between income groups}

For all income groups, products from cultivated/purchased plants account for the primary source for substitution (63.6 $\%$ to $76.5 \%)$, followed by animal/ other products $(17.6 \%$ to $18.8 \%$ ) and other wild plant species (5.9\% to $18.2 \%)$. Whilst accounting for a minor share in substitution generally, these alternative local plant species, however, are of high importance to the very low $(18.2 \%)$ and medium $(12.5 \%)$ income groups.

For P. biglobosa and A. digitata, the choice of substitutes differed significantly between income groups $(\chi 2=19.8, \mathrm{p}<$ $0.01 ; \chi 2=15.4, \mathrm{p}<0.01$ respectively), while it did not differ significantly for $V$. paradoxa $(\chi 2=4.38, p>0.05)$ (Fig. 2).

Furthermore, a higher proportion of the poorer households (= very low income) reported to have no substitutes for the three NTFP species compared to the less poor households (= medium income and above medium income). For V. parado$x a$ seeds, $20 \%$ of the poorest households, and $10 \%$ of the less poor, lack appropriate substitutes. Above all, wild and, thus, free alternatives were not mentioned.

For P. biglobosa, even $30 \%$ of the poorest households lack a proper substitution, compared to $10-15 \%$ of the less poor households ( $=$ medium income and above medium income). Less poor households preferably replace the raw material for moutarde with fish, being the more expensive alternative, while poorer households use the cheaper manufacture produce MAGGI cubes. 
Income groups

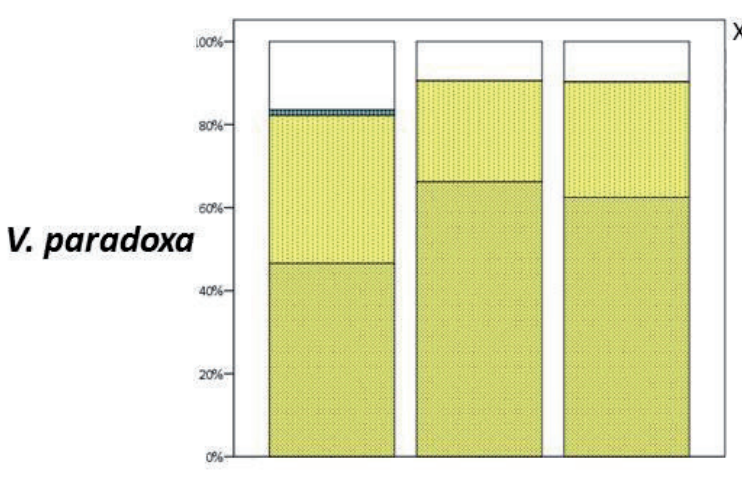

\section{Ethnic groups}
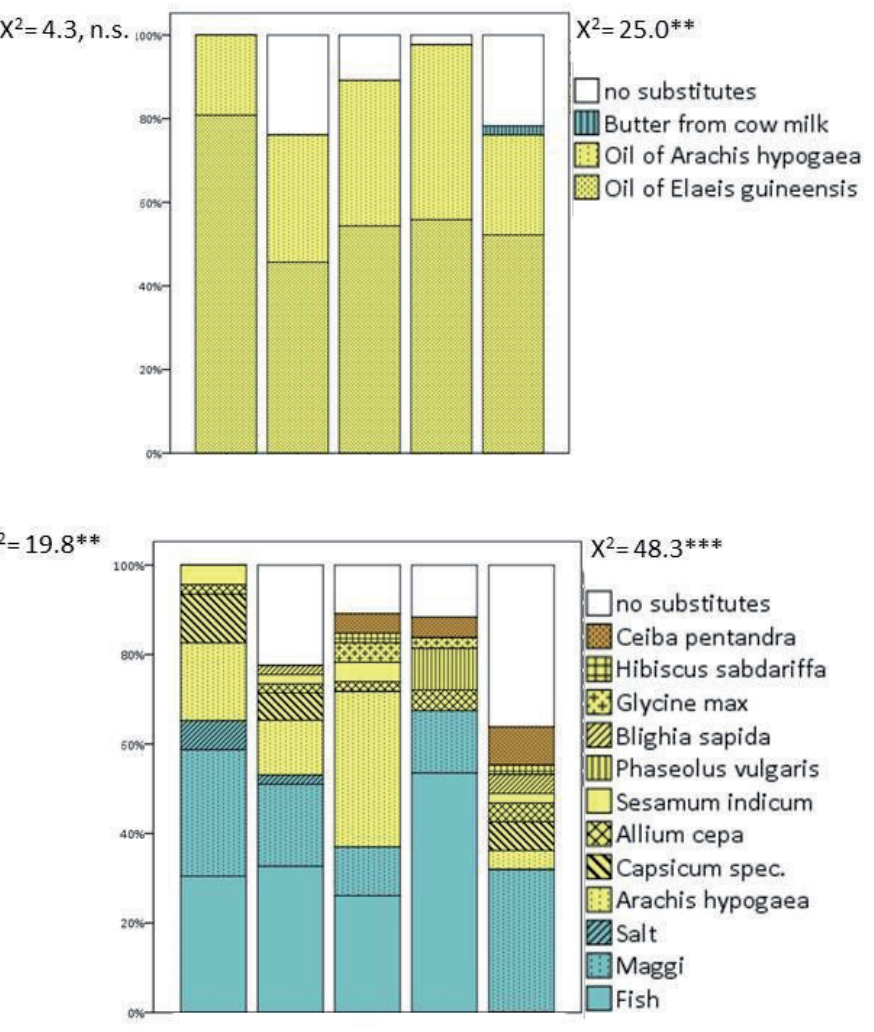

$X^{2}=35.6^{* * *}$

$\square$ no substitutes

$\mathbb{Z}$ Parinari curatellifolia

$\square$ Vitex doniana

Lycopersicum esculentum

目Abelmoschus esculentus

ZB Blighia sapida

Arachis hypogaea

$\square$ sesamum indicum
A. digitata

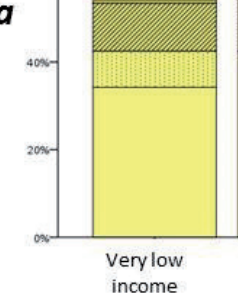

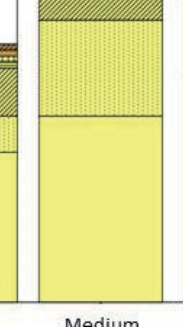

Medium
income

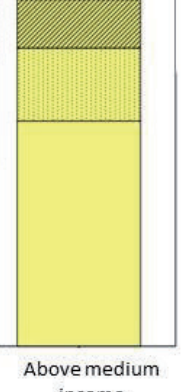

income

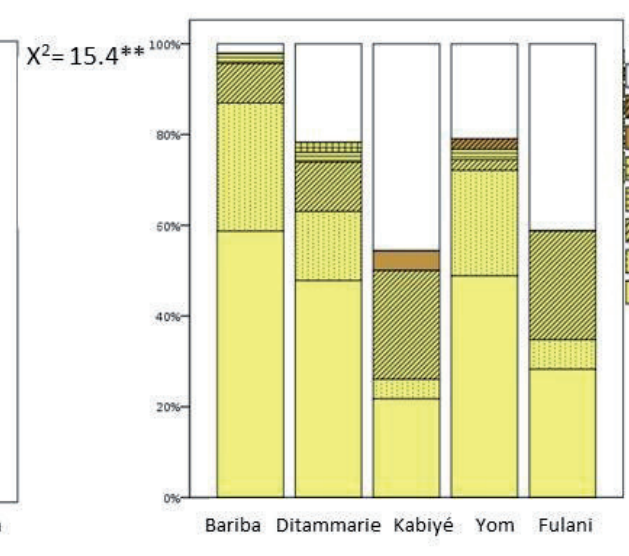

Fig. 2: Differences in substitution patterns of NTFPs between income and ethnic groups. Blue $=$ animal $/$ other products; yellow $=$ cultivated $/$ purchased plants; brown $=$ other NTFP species. $* \mathrm{p}<0.05 ; * * \mathrm{p}<0.01 ; * * * \mathrm{p}<0.001 ; \mathrm{n} . \mathrm{s}$. $=$ not significant. / Différences dans les modèles de substitution des PFNL entre groupes économiques (de revenu) et groupes ethniques. Bleu $=$ animal $/$ autres produits; jaune $=$ plantes cultivées / achetées; brun = autres espèces de PFNL. * $\mathrm{P}<0,05 ; * * \mathrm{p}<0,01 ; * * * \mathrm{p}<0,001$; N.s. = Pas significatif.

For A. digitata, as much as $40 \%$ of the sampled poorest households (and even $30 \%$ and $20 \%$ of the medium and above medium income groups, respectively) stated to have no replacement. Again, less poor households can afford to purchase more costly products (peanuts, sesame, seeds of $B$. sapida) while the poorest ones engage in the collection of the two wild plant species ( $V$. doniana and Parinari curatellifolia) to use as substitute for sauce ingredient.

\subsection{Differences in substitution patterns between ethnici- ties}

For all three species, our analysis revealed significant differences in substitution patterns between ethnic groups (Fig. 2): A. digitata $(\chi 2=35.6, \mathrm{p}<0.001)$, P. biglobosa $(\chi 2=48.3$, $\mathrm{p}<0.001)$ and $V$. paradoxa $(\chi 2=25.0, \mathrm{p}<0.01)$. Albeit resembling regarding the total number of alternatives, they differ significantly especially for $P$. biglobosa (only two matches out of twelve substitutes) and A. digitata (only three matches out of seven substitutes).

Due to the very low number of alternatives, replacement of $V$. paradoxa seeds does not show great alterations between groups (except that the Fulani were the only ethnic group that mentioned cow butter as an additional substitute). In contrast, substitution patterns for P. biglobosa are highly differentiated between ethnic groups. Fish was mentioned as primary substitute by the four tiller societies Bariba, Ditammarie, Kabiyé and Yom, while the Fulani's first choice is MAGGI cubes when seeds of $P$. biglobosa are unavailable. 
Moreover, the Bariba and the Ditammarie only mentioned cultivated and other merchandise as alternatives to moutarde, while the Kabiyé, the Yom and the Fulani also count on alternative wild plant species.

For the seeds of $A$. digitata, the Fulani only cited the three most important substitutes regarding the overall sample (sesame, peanuts, and the seeds of B. sapida), while the other ethnicities additionally reported other substitutes. For instance, the Ditammarie exclusively cited tomato, the Kabiyé leaves of $V$. doniana, and the Yom seeds of $P$. curatellifolia, with the latter being the only two wild plant species mentioned here.

Overall, about $15 \%$ of all substitutes reported by the Kabiyé and Yom were alternative wild plant species (Table 4). In contrast, the Ditammarie never mentioned other wild plant species as substitutes for the three investigated NTFPs.

Interestingly, the autochthon Bariba displayed the lowest proportion of respondents having no substitutes for the three species (Fig. 2), while particularly the Fulani seem to have difficulties to substitute the investigated NTFPs.

\section{Discussion}

As our analysis shows, rural communities use a wide range of different products to substitute the seeds of the three investigated local NTFP species, Vitellaria paradoxa, Parkia biglobosa and Adansonia digitata. Of the 18 substitutes mentioned in total, $61 \%$ are cultivated/purchased plants, $22 \%$ animal or other products, and $17 \%$ wild plant species collected in the adjacent savanna areas.

However, there are considerable differences in substitution patterns between both income groups and ethnic groups. From our figures, it becomes evident that income has a significant effect on the choice of alternatives, reflecting differences in financial resources to access these substitutes for the NTFPs under investigation. Being the ones with the least range of alternative products and least financial means to engage in pricy products, the poorest households are likely to be the ones most affected by the absence of the inve- stigated NTFPs. Other wild plant species, thus, are essential to meet basic household needs as they are low cost opportunities with relatively easy access. In contrast, purchased/ cultivated products are often pricy and sufficient quantities remain unaffordable for very poor households.

However, there may be justified assumption that a decreasing occurrence of $V$. paradoxa, $P$. biglobosa and A. digitata not only will hit the poorest but rather all their beneficiaries. Evidence is presented by a recent study conducted by HeUBES et al. (2012) in Northern Benin who showed that the occurrence of the three target species and, subsequently, their contributions to household economies, will be severely affected by predicted land use and climate change until 2050. For $V$. paradoxa, losses of $20 \%$ up to $50 \%$ in 2050 are estimated for the study area. The same holds true for P. biglobosa (losses up to $50 \%$ ) and $A$. digitata (losses up to $20 \%$ ).

Subsequently, the daily supply of fat and protein as provided by these three species and, thus, their contributions to dietary needs, might be threatened in the future. This particularly holds true for shea nuts as there exist only few alternatives for them as our study showed. Even if the fat content of these substitutes is similar to that of shea nuts the fat quality might be lower, and their production costs, however, differ much compared to that of shea butter. While the manufacture of shea butter originally is an individual householdbased activity carried out by women using firewood and simple wooden tools, the processing of peanut oil requires mills, i.e. technical equipment which normally is not affordable on a household level. Instead, households would need to pay mill owners. The production process of palm oil (Elaeis guineense) is by far the most expensive one, as interviewed women reported, including the harvest of the seeds. The subsequent processing requires larger machines and substantial energy use, which normally is centralized in specialized production sites. In addition, the palm tree is very scarce in the region, making its products far too expensive to be used on a daily basis. Furthermore, alternative products from other NTFP species to substitute $V$. paradoxa were not cited by our interviewees, and the production and use of butter from cow milk remains with merely a couple

Table 4: Total number of substitutes for the three species, separated per income group and ethnicity. / Nombre total de substituts pour les trois espèces, séparés par groupe de revenu et groupe ethnique.

\begin{tabular}{|c|c|c|c|c|c|c|}
\hline & \multirow[t]{2}{*}{ V.paradoxa } & \multirow[t]{2}{*}{ P. biglobosa } & \multirow[t]{2}{*}{ A. digitata } & \multicolumn{3}{|c|}{ Share by category $(\%)$} \\
\hline & & & & $\begin{array}{l}\text { Product of a culti- } \\
\text { vated or purchased } \\
\text { plant species }\end{array}$ & $\begin{array}{l}\text { Product of a wild } \\
\text { plant species }\end{array}$ & $\begin{array}{l}\text { Purchased animal } \\
\text { or other products }\end{array}$ \\
\hline \multicolumn{7}{|l|}{ Income groups } \\
\hline Very low income & 3 & 12 & 7 & 63.6 & 18.2 & 18.2 \\
\hline Medium income & 2 & 10 & 4 & 68.8 & 12.5 & 18.8 \\
\hline Above medium income & 2 & 11 & 4 & 76.5 & 5.9 & 17.6 \\
\hline No. of substitutes overlapping* & 2 & 10 & 3 & & & \\
\hline \multicolumn{7}{|l|}{ Ethnic groups } \\
\hline Bariba & 2 & 7 & 4 & 78.6 & 7.1 & 14.3 \\
\hline Ditammarie & 2 & 8 & 5 & 80.0 & 0.0 & 20.0 \\
\hline Kabiyé & 2 & 8 & 4 & 71.4 & 14.3 & 14.3 \\
\hline Yom & 2 & 6 & 5 & 69.2 & 15.4 & 15.4 \\
\hline Fulani & 3 & 8 & 3 & 78.6 & 7.1 & 14.3 \\
\hline No. of ubstitutes overlapping* & 2 & 2 & 3 & & & \\
\hline
\end{tabular}


Fulani households owning few cattle. Apart from that, the calcium content of shea butter (340 mg/100 g; DEI 2008) by far exceeds that of peanuts $(92 \mathrm{mg} / 100 \mathrm{~g}$; ATAGA \& VAN DER VOSSEN 2007), palm oil seeds (60 mg/100 g; NTARE 2007) and cow milk butter (72 mg/100 g; USDA 2002). This is in line with findings of LEAKEY (1999) who found that the biochemical profiles of native species are often superior to exotic species in terms of essential fat, micronutrients, fiber and protein. In contrast to the case of shea nuts, the options mentioned to replace protein-rich seeds of $P$. biglobosa are not as sufficient in terms of nutritional values (Table 5). Apart from peanuts and the seeds of the local species Ceiba pentandra, none of the alternatives cited reaches similar protein contents. Additionally, despite being an adequate nutritional substitute $C$. pentandra is very scarce in the study area - a possible reason for the low mention by respondents (3.5\%). This pattern is reflected for A. digitata. None of the seeds of the three cultivated plants reported as replacements equals its protein shares (Table 5), nor does the alternative wild local species Vitex doniana. However, being quite abundant in the region, the latter presents at least a low cost alternative.

In addition, those substitutes which compensate best in terms of fat and protein supply are all cultivated species (peanuts, sesame and B. sapida), i.e. they require access to farmland. This, however, often is limited for the poorest households as the size of farmland they manage is often insufficient (HeUBACH et al. 2011). Hence, we expected to find a greater proportion of other wild plant species used as substitutes, particularly among the poorer households. However, this is not the case. This might probably due to the low abundance of these species in the area as reported by the interviewees. Native species might also be less interesting if they have comparably lower productivities than e.g. crop species, which can be produced in relatively stable and controllable conditions (NEUfELDT et al. 2012), and generally are located nearby homes.

Beyond socio-economic characteristics, ethnic affiliation seems to play a considerable role in choosing substitutes for the three target species. Overall, in the study region, there is quite a range of species whose products are commonly valued by all investigated ethnic groups, such as the three species investigated here, plus a great range of NTFP species used considerably differently (HeUBACH et al. 2013). This is in line with findings of FANDOHAN et al. (2010) who identified use values for 76 plant species among three ethnic groups (Berba, Gourmantche and Waama) in Northern Benin, also highlighting the influence of gender and market proximity on plant use. Particularly woody species were most commonly used by all respondents, including the target species of the study at hand, while a whole set of other plant species were exclusively used by specific ethnic groups. This pattern is in accordance with other recent studies looking either at a collection of plant species (e.g. LYKKE et al. 2004; Vodouhê et al. 2009; PArÉ et al. 2010; SoP et al. 2012) or single species uses such as e.g. Adansonia digitata (DE CAluwÉ et al. 2009; SCHUMANn et al. 2011), Tamarindus indica (FANDOHAN et al. 2010) or Sclerocarya birrea (GouWAKINNOU et al. 2011).
The reported differences reflect preferences of plant and other product use, often brought along from other regions through migratory activities (four of the five ethnic groups migrated into the study area). Particularly for P. biglobosa and $A$. digitata, there is only low intersection of substitutes between the five ethnic groups. Four of five groups engage in both purchasing/cultivating products and NTFP collection - except Ditammarie people. Additionally, the Ditammarie are among the two ethnic groups which frequently mentioned not to have alternatives at all; the other one is the Fulani group. In contrast, a high proportion of alternative NTFP species, as identified with the Kabiyé and Yom, might also indicate low financial means to access marketed products and/or limited access to farmland to cultivate them oneself. However, insights from НеuBACH et al. (2011) suggest that there is no significant difference regarding land holding between groups. To further understand the underlying reasons for the choice of substitutes more research at the household level is needed.

\section{CONCLUSION}

If the provision of seeds of Vitellaria paradoxa, Parkia biglobosa and Adansonia digitata is limited, rural communities in savanna areas could built on a wide range of cultivated, purchased or wild plant and animal products to substitute for these NTFPs. However, the three species of focus remain superior to all of their substitutes both in terms of their contribution to daily diets and accessibility. They generally exceed their alternatives in terms of protein, fat and micronutrients, and they are semi-open access resources readily available without requiring costly financial means or equipment. Thus, they are most attractive to the rural poor. However, this unique combination of characteristics also reflects the other side of the medal: maintaining the supply of those NTFPs is most crucial for the poorest households and thus will be a major future challenge to secure a healthy, self-sufficient food provision and income sources.

Subsequently, there is concern to maintain the availability of $V$. paradoxa, P. biglobosa and A. digitata in existing agroforestry systems. To support this, future research should have a closer look at how tree domestication, seed quality and genetic diversity of the three focus species could help to improve yields, and underlying reasons for substitution patterns to help developing appropriate management measures.

\section{ACKNOWLEDGMENTS}

The present study was conducted at the Biodiversity and Climate Research Centre (BiK-F), Frankfurt am Main, Germany, and funded by the research funding programme "LOEWE - Landes-Offensive zur Entwicklung Wissenschaftlich-Ökonomischer Exzellenz" of Hesse's Ministry of Higher Education, Research, and the Arts. The authors are grateful to Gnanando Saidou and Laurent Akissatom who assisted in field work, and to all respondents who took part in the survey. Further sincere thanks go to Prof. Brice Sinsin (University of Abomey-Calavi, Benin) for scientific and logistic support, and the EU-funded project UNDESERT (understanding and combating desertification to mitigate its impact on ecosystem services, EU-FP7). 


\section{References}

Angelsen A \& Wunder S (2003): Exploring the forest-poverty link: key concepts, issues and research implications. CIFOR Occasional Paper 40: Bogor, Indonesia.

Angelsen A, Jagger P, Babigumira R, Belcher B, Hogarth NJ, Bauch S, Börner J, Smith-Hall, C \& Wunder S (2014): Environmental income and rural livelihoods: A global-comparative analysis. World Dev 64: 12-28.

Arnold M, Powel B, Shanley P \& Sunderland T (2011): Editorial: Forests, biodiversity and food security. Int Forest Rev 13: 259-264.

Ataga CD \& VAN DER Vossen HAM (2007): Elaeis guineensis Jacq. Record from PROTA4U. VAN DER VOSSEN HAM \& Mkamilo GS (eds) PROTA (Plant Resources of Tropical Africa / Ressources végétales de l'Afrique tropicale), Wageningen, Netherlands. http://www.prota4u.org/search.asp.

Babulo B, Muys B, Nega F, Tollens E, Nyssen J, DeCKERS J, \& MATHIJS E (2009): The economic contribution of forest resource use to rural livelihoods in Tigray, Northern Ethiopia. Forest Policy Econ 11: 109-117.

BelCHER BM (2003): What isn't an NTFP? Int Forest Rev 5: 161-168.

BofFA JM (1999): Agroforestry parklands in sub-Saharan Africa. FAO, Rome, Italy.

Bolwig S \& PaArup-Laursen B (1999): Nature, work, culture: labour utilisation in agriculture and off-farm employment among the Fulani in northern Burkina Faso. Danish J Geogr Special Issue 2: 27-41.

BRINK AB \& EvA HD (2009): Monitoring 25 years of land cover change dynamics in Africa: A sample based remote sensing approach. Appl Geogr 29: 501-512.

Bundschun TV, Hahn K \& WitTig R(2011): The medicinal plants of the woodlands in northern Malawi (Karonga district).Flora Veg Sudano-Sambesica 14: 3-8.

CAVENDish W (2000): Empirical regularities in the povertyenvironment relationship of rural households: Evidence from Zimbabwe. World Dev 28: 1979-2003.

CAvendish W (2002): Quantitative methods for estimating the economic value of resource use to rural households. In CAMPBELl MB \& LUCKeRT KME (eds) Uncovering the hidden harvest. Valuation methods for woodland and forest resources. Earthscan Publications Ltd., London.

CIFOR (2011): Forests and non-timber forest products. CIFOR fact sheets. http://www.cifor.cgiar.org/publications/corporate/factSheet/NTFP.htm.

Cunningham AB, Ayuk E, Franzel S, Duguma B \& AsANGA C (2002): An economic evaluation of medical tree cultivation, Prunus africana in Cameroon. People and Plants Working Paper 10. UNESCO, France.

Dah-Dovonon J\& GNANGLe CP (2006): Evaluation des potentialités de développement de la filière karité dans les départements de l'Atacora et de la Donga: Rapport définitif ProCGRN, GTZ, Natitingou, Benin.

De Bruijn ME \& DiJK JWM (1994): Drought and coping strategies in Fulbe society in the Hayre (Central Mali): a historical perspective. Cahiers d'études africaines 34: 85-108.

De Caluwé E, De Smedt S, Assogbadjo Ae, Samson R, Sinsin B \& Van Damme P (2009): Ethnic differences in use value and use patterns of baobab (Adansonia digitata L.) in northern Benin. Afr J Ecol 47: 433-440.
De Merode E, Homewood K \& Cowlishaw G (2004): The value of bushmeat and other wild foods to rural households living in extreme poverty in Democratic Republic of Congo. Biol Conserv 118: 573-581.

DEATON A (1982): Inequality and needs - some experimental results for Sri-Lanka. Popul Dev Rev 8: 35-49.

Dei HK, Rose SP, Mackenzie AM \& Pirgozliev V (2008): Metabolizable energy in different shea nut (Vitellaria paradoxa) meal samples for broiler chickens. Poultry Sci 87: 694-699.

Fandohan B, Assogbadjo A, KakaÏ R, Kyndt T, CaluwÉ E, Codjia J \& Sinsin B (2010): Women's traditional knowledge, use value, and the contribution of Tamarind (Tamarindus indica L.) to rural households' cash income in Benin. Econ Bot 64: 248-259.

Foppes J \& KetPHANH S (2004): Non-timber forest products for poverty reduction and shifting cultivation stabilization in the uplands of Lao PDR. Paper prepared for the NAFRI Workshop on Poverty Reduction and Shifting Cultivation Stabilization in the Uplands of Lao PDR: Technologies, approaches and methods for improving upland livelihoods, January 27-30.

Gouwakinnou GN, Lykke AM, Assogbadjo AE \& Sinsin B (2011) : Local knowledge, pattern and diversity of use of Sclerocarya birrea. J Ethnobiol Ethnomed 7:8.

HagenaArs A, De Vos \& K, Zaidi MA (1994): Poverty Statistics in the Late 1980s: Research Based on Micro-data. Office for Official Publications of the European Communities, Luxembourg.

HASSAN LG \& UMAR KJ (2005): Protein and amino acids composition of African locust bean (Parkia biglobosa). Trop. Subtrop Agroecosyst 5: 45-50.

Heubach K, Wittig R, Nuppenau EA \& Hahn K (2011): The economic importance of non-timber forest products (NTFPs) for livelihood maintenance of rural West African communities: A case study from northern Benin. Ecol Econ 70: 1991-2001.

Heubach K, Wittig R, Nuppenau EA \& Hahn K (2013): Local values, social differentiation and conservation efforts: The impact of ethnic affiliation on the valuation of NTFPspecies in Northern Benin, West Africa. Hum Ecol 41: 513533.

Heubes J, Heubach K, Schmidt M, Wittig R, Zizka G, NuPPENAU EA \& HAHN K (2012): Impact of future climate and land use change on non-timber forest product provision in Benin, West Africa: Linking niche-based modeling with ecosystem service values. Econ Bot 66: 383-397.

IPCC (2007): Climate Change 2007: The physical science basis. Contribution of working group I to the fourth assessment report of the intergovernmental panel on climate change. Cambridge.

Kalaba FK, Quinn C \& Dougill A (2013): Contribution of forest provisioning ecosystem services to rural livelihoods in the Miombo woodlands of Zambia. Popul Environ 35: 159-182.

Kamanga P, Vedeld P \& SJaAstad E (2009): Forest incomes and rural livelihoods in Chiradzulu District, Malawi. Ecol Econ 68: 613-624.

KEPE T (2008): Beyond the numbers: Understanding the value of vegetation to rural livelihoods in Africa. Geoforum 39: 958-968. 
Kronborg M, Ilboudo JB, Bassolé IHN, Barfod AS, RAVN HW \& LYKKE AM: (2014): Correlates of product quality of soumbala, a West African non-timber forest product. Ethnobot Res Appl 12: 25-28.

LEAKEY RRB (1999): Potential for novel food products from agroforestry trees. Food Chem 66: 1-14.

Lessmeister A, Schuman n K, LykKe AM, Heubach K, Thiombiano A \& Hahn K (2015): Substitution of the most important and declining wild food species in southeast Burkina Faso. Flora Veg Sudano-Sambesica 18: 11-20.

LYKKe AM, KRISTENSEN MK \& GANABA S (2004): Valuation of local use and dynamics of 56 woody species in the Sahel. Biodivers Conserv 13: 1961-1990.

Maranz S, Kpikpi W, Wiesman Z, de Saint Sauveur A \& Chapagain B (2004): Nutritional values and indigenous preferences for shea fruits (Vitellaria paradoxa C.F. Gaertn. F.) in African agroforestry parklands. Econ Bot 58: 588-600.

Mayaux P, Bartholomé AC, Cherlet M, Defourny P, di Gregorio A, Diallo O, Massart M, Nonguierma A, Pekel JF, Pretorius C, Vancutsem C \& Vasconcelos M (2003): The land cover map for Africa in the year 2000 . GLC2000 database. European Commission Joint Research Centre.

Mertz O, LykKe AM \& ReEnberg A (2001) Importance and seasonality of vegetable consumption and marketing in Burkina Faso. Econ Bot 55: 276-289.

NDAm N \& Marcelin MT (2004): "Chop, but no broke pot": the case of Prunus africana on Mount Cameroon. In Sunderland T \& Ndoye O (eds) Forest Products, Livelihoods and Conservation: Case Studies of Non-Timber Forest Product Systems, Volume 2 - Africa. Center for International Forestry Research, Bogor 37-52.

Neufeldt H, Dawson IK, Luedeling E, Ajayi OC, BeeDy T, Gebrekirstos A, Jamnadass RH, König K, Sileshi GW, Simelton E, Montes CS \& Weber JC (2012): Climate change vulnerability of agroforestry. ICRAF Working Paper No 143, World Agroforestry Center, Nairobi.

Nordeide MB, Hatloy A, Folling M, Lied E \& Oshaug A (1996): Nutrient composition and nutritional importance of green leaves and wild food resources in an agricultural district, Koutiala, in Southern Mali. Int J Food Sci Nutr 47: 455-468.

NTARE BR (2007): Arachis hypogaea L. Record from PROTA4U. van DER Vossen HAM \& MKamilo GS (eds) PROTA (Plant Resources of Tropical Africa / Ressources végétales de l'Afrique tropicale), Wageningen, Netherlands. http:// www.prota4u.org/search.asp.

Paré S, Savadogo P, Tigabu M, Ouadba J \& Odén P (2010): Consumptive values and local perception of dry forest decline in Burkina Faso, West Africa. Environ Dev Sustain 12: 277-295.

Schreckenberg K, Awono A, Degrande A, Mbosso C, Ndoye O \& TCHOUndueu Z (2006): Domesticating indigenous fruit trees as a contribution to poverty reduction. Forest Trees Livelihoods 16: 35-51.
Schumann K, Wittig R, Thiombiano A, Becker U \& HAHN K (2011): Impact of land-use type and harvesting on population structure of a non-timber forest product-providing tree in a semi-arid savanna, West Africa. Biol Conserv 144: 2369-2376.

Shackleton CM \& Shackleton SE (2006): Household wealth status and natural resource use in the Kat River valley, South Africa. Ecol Econ 57: 306-317.

Shackleton CM, McGarry D, Fourie S, Gambiza J, Shackleton SE \& FAbricius C (2007): Assessing the effects of invasive alien species on rural livelihoods: Case examples and a framework from South Africa. Hum Ecol 35: 113-127.

Shackleton S, Campbell B, Lotz-Sisitka H \& ShackLETON C (2008): Links between the local trade in natural products, livelihoods and poverty alleviation in a semi-arid region of South Africa. World Dev 36: 505-526.

Sieglstetter R, Hahn K \& Wittig R (2011): The use of woody species in northern Benin.- Flora Veg Sudano-Sambesica 14: 19-23.

Sop T, Oldeland J, Bognounou F, Schmiedel U \& ThIOMBIANO A (2012): Ethnobotanical knowledge and valuation of woody plants species: a comparative analysis of three ethnic groups from the sub-Sahel of Burkina Faso. Environ Dev Sustain 14: 627-649.

TeKLehaimanot Z (2004): Exploiting the potential of indigenous agroforestry trees: Parkia biglobosa and Vitellaria paradoxa in sub-Saharan Africa. Agroforest Syst 61: 207220 .

USDA (2002): National nutrient database for standard reference release 27 in USDA. http://ndb.nal.usda.gov/ndb/ foods/show.

Vedeld P, Angelsen A, Bojö J, Sjaastad E \& Kobugabe BERG G (2007): Forest environmental incomes and the rural poor. Forest Policy Econ 9: 869-879.

Vodouhê F, Coulibaly O, Greene C \& Sinsin B (2009): Estimating the local value of non-timber forest products to Pendjari biosphere reserve dwellers in Benin. Econ Bot 63: 397-412.

Wittig R, KöNig K, Schmidt M \& Szarzynski J (2007): A study of climate change and anthropogenic impacts in West Africa. Environ Sci Pollut R 14: 182-189.

World Agroforestry Center (2013): Agroforestry, food and nutritional security. Background paper for the international conference on forests for food security and nutrition, FAO, Rome, 13-15 May, 2013.

WORLD BANK TW (2004): Sustaining forests: A development strategy. The World Bank, Washington, D.C.

WORLD BANK TW (2008): Forests sourcebook: Practical guidance for sustaining orests in development cooperation. The World Bank, Washington, D.C.

WORLD Resources Institute (2005): The wealth of the poor-managing ecosystems to fight poverty. World Resources Institute, Washington, D.C. 